\title{
EXAMINATION OF THE SEMEN AND ERYTHROCYTES OF SEVEN SPECIES FOR IMMUNOLOGICAL CROSS-REACTION
}

\author{
B. A. BALDO* AND B. BOETTCHER \\ School of Biological Sciences, The Flinders University of South Australia, \\ Bedford Park, South Australia 5042
}

(Received 2nd May 1970, revised 11th August 1970)

\begin{abstract}
Summary. Using a haemagglutination technique, heterologous antisera to both the seminal plasma and spermatozoa of man, possum, rabbit and ram and the whole homogenized epididymis and vas deferens of the rat, were found to show immunological cross-reaction with homologous erythrocytes. Cross-reaction between rabbit antiserum to rooster seminal plasma and chicken erythrocytes was observed, but cross-reaction was not seen with antiserum to rooster spermatozoa.

Rabbit antiserum to bull seminal plasma haemolysed bovine erythrocytes, but haemolysis was not observed with antiserum to bull spermatozoa.

The results obtained are discussed with particular reference to other papers reporting such cross-reacting antigens.
\end{abstract}

\section{INTRODUCTION}

An antigen, or antigens, common to erythrocytes and to spermatozoa of the one species has been demonstrated in the ram (Moxter, 1900; Rosenthal, 1912; see also Landsteiner, 1945) and, more recently, in man (Popivanov \& Vulchanov, 1961, 1962; Edwards, Ferguson \& Coombs, 1964).

There are some conflicting reports that the same is true for the bull. The majority of investigators have been unable to demonstrate a common antigen (Menge, Stone, Tyler \& Gasida, 1962; Schmid, Conneally \& Stone-unpublished observations, see Stone, 1964; Matousek, 1964; Drevius, 1968), though Docton, Ferguson, Lazear \& Ely (1952) reported that bull spermatozoa contained bull erythrocyte antigens. There seems to be general agreement, however, that the J blood group substance occurs both on the erythrocytes and in the seminal plasma of some bulls (Stone, 1962).

Menge et al. (1962) were unable to find evidence of cross-reacting antigens on the spermatozoa and erythrocytes of rabbits. Piko \& Tyler (1963) found that antiserum to epididymal spermatozoa from the Chinese hamster showed crossreaction not only with hamster erythrocytes but also with hamster spleen and brain.

* Present address: Department of Microbiology, College of Physicians and Surgeons, Columbia University, New York, N.Y. 10032. 
The conflicting results regarding the presence of the ABO blood group antigens and the $\mathbf{D}$ antigen of the $\mathrm{Rh}$ series on human spermatozoa have been discussed by Boettcher (1968). Although some workers have reported finding the D antigen on spermatozoa (Gullbring, 1957; see also Levine \& Celano, 1961; Quinlivan \& Masouredis, 1962), Lawler \& Shatwell (1962) have suggested that the $\mathrm{D}$ antigen is unlikely to be found anywhere but on the human erythrocyte. Popivanov \& Vulchanov (1968) agreed with the suggestion of Edwards et al. (1964), that the common antigen(s) on human spermatozoa and erythrocytes is a species-specific antigen(s) and this antigen(s) is probably also common to other cells of the human body.

The original purpose of this study was to gain more information on the serology and chemical nature of the antigen(s) common to human erythrocytes and spermatozoa. In order to see whether or not the cross-reaction reported for these cells in man, and in the ram, is more widespread, a preliminary examination was carried out using seminal material from seven species.

Using a haemagglutination technique, heterologous antisera to spermatozoa and seminal plasma of man, rabbit, possum, rooster, bull and ram and to spermatozoa from the vas deferens and epididymis of the rat, were examined for cross-reaction with erythrocytes of the same species.

\section{MATERIALS AND METHOD}

\section{Animal semen}

Human semen samples were obtained from the South Australian Institute of Medical and Veterinary Science, Adelaide. Spermatozoa were removed by centrifugation, and were washed six times with physiological saline. Spermatozoa from all species (except rat) used in these experiments were washed in this way.

Rabbit semen was obtained from a single buck with the aid of an artificial vagina. Because of the solid nature of the rat ejaculate, vas deferens and epididymal tissue were injected instead of seminal plasma and spermatozoa. Mature adult male albino rats were killed by ether inhalation, or by exsanguination, and the vas deferens and epididymides immediately excised. These organs were homogenized in sterile normal saline with a high speed UltraTurrax (type TP 18/2) mixer and used for injection. Material equivalent to two vasa deferentia and half an epididymis was given at each injection of the rabbits used to raise antisera to this species.

Mature male brush-tail possums (Trichosurus vulpecula), were anaesthetized using a mixture of nitrous oxide and oxygen. It was found with some animals that, at the point where they began to regain consciousness, spontaneous ejaculation often occurred and the semen could be collected in a wide-mouthed container. Up to $15 \mathrm{ml}$ of semen was obtained from one possum by this method.

Pooled rooster semen was collected by massage of several mature White Leghorns.

Pooled ram semen, obtained from three Merino rams by electroejaculation, was provided by Dr R. Seamark, Department of Animal Physiology, Waite Agriculture Research Institute, S.A. 
Pooled bull semen was obtained from the Artificial Insemination Centre, Department of Agriculture, Northfield, S.A., from bulls used as donors at the centre.

In all cases, spermatozoa and seminal plasma were stored at $-20^{\circ} \mathrm{C}$.

\section{Production of antisera}

Antibodies to human and rabbit seminal plasma and spermatozoa were prepared in mice and all other antisera were prepared in rabbits. For injection, undiluted seminal plasma and $5 \% \mathrm{v} / \mathrm{v}$ suspensions of washed spermatozoa in physiological saline were used. Antigen solutions before injection were mixed with penicillin $(10,000 \mathrm{U} /$ rabbit and $1000 \mathrm{U} /$ mouse), and streptomycin (10 $\mathrm{mg} / \mathrm{rabbit}$ and $1 \mathrm{mg} /$ mouse).

\section{Injection of mice}

Twelve Swiss Albino male mice were given initial subcutaneous injections of $0.25 \mathrm{ml}$ of a mixture of equal parts of Freund's complete adjuvant and the antigen (seminal plasma or washed spermatozoa in saline) at two sites on the back. A booster dose of $0.5 \mathrm{ml}$ of the antigen solution alone was given intraperitoneally (i.p.) 2 weeks after the first injection, and was repeated at weekly intervals thereafter.

Mouse anti-human $\mathrm{O}$ red-cell serum was obtained by injecting fifteen mature Swiss albino male mice i.p. with $0.5 \mathrm{ml}$ of a $10 \%$ suspension of washed human $\mathrm{O}$ Rh-negative red cells in physiological saline. After an interval of 14 days, a second injection identical with the first was given. Animals were bled 14 days after the second injection. The serum titre against $O \mathrm{Rh}$-negative red cells, determined by haemagglutination, was 2048 .

\section{Injection of rabbits}

An initial dose of $0.5 \mathrm{ml}$ of seminal plasma (or washed spermatozoa in saline), emulsified with $0.5 \mathrm{ml}$ of Freund's complete adjuvant was injected intramuscularly (i.m.) into each hind leg of a New Zealand white rabbit. This dose was repeated after 14 days and followed up with i.p. injections of $1 \mathrm{ml}$ of antigen (no adjuvant) at weekly intervals.

In the case of animals injected with human seminal plasma and spermatozoa, antisera were obtained at least 3 months after the original injection. For the results described in this communication, antisera to rabbit, rat, possum, bull, ram and rooster antigens were taken for testing 1 week after the first i.p. injection.

\section{Bleeding of animals}

Mice were bled from the retro-orbital plexus using glass Pasteur pipettes. Rabbits were bled from the ear veins. Normal and immune sera were stored at $-20^{\circ} \mathrm{G}$.

\section{Destruction of haemolytic activity}

Heating sera at $56^{\circ}$ to $58^{\circ} \mathrm{C}$ in a water bath for $30 \mathrm{~min}$ in all cases removed haemolytic activity for all types of erythrocytes examined. 


\section{Erythrocytes}

Human erythrocytes in Rous-Turner solution were obtained from the Red Gross Blood Transfusion Centre, Adelaide. Rabbit, rat, possum, chicken, sheep, bovine, horse and duck erythrocytes were obtained fresh as needed by bleeding animals directly into Alsever's solution. 'Bombay' erythrocytes were obtained frozen in a glycerol-citrate solution. Preparation of the human and animal erythrocytes for use in haemagglutination, and haemagglutination inhibition, and a description of these two techniques as used here have been published (Baldo \& Boettcher, 1970).

\section{Test for spermagglutinins}

One volume of freshly ejaculated motile human spermatozoa standardized to $2 \times 10^{7}$ cells $/ \mathrm{ml}$ using a Petrof-Hausser bacteria counter, was mixed with 5 vol of serum (previously heated to $56^{\circ}$ to $58^{\circ} \mathrm{C}$ for $30 \mathrm{~min}$ ) and incubated at $37^{\circ} \mathrm{C}$ with constant shaking (100 oscillations/min).

Samples were taken from the mixture at 15-, 45- and 120-min intervals and examined under phase contrast on a microscope slide at $\times 400$ magnification. Spermagglutinating activity was estimated by counting the number of agglutinates seen per 100 motile, unagglutinated spermatozoa.

\section{RESULTS}

In order to determine whether or not the agglutination of human erythrocytes by mouse anti-human seminal plasma and anti-human spermatozoa was specific for human erythrocytes, red cells of a number of other species were also tested with these two antisera. No cross-reaction was detected between the antisera and the erythrocytes from rabbit, rat, sheep, bull, possum and horse. However, chicken and duck erythrocytes appeared to show some cross-reaction with mouse anti-human seminal plasma (Table 1). Agglutination of the 'Bombay' erythrocytes (Table 1) indicated that the erythrocyte agglutinins present in the anti-human seminal plasma and the anti-human spermatozoa

TABLE 1

REACTION OF NORMAL MOUSE SERUM AND SERA FROM MICE IMMUNIZED WITH HUMAN SEMINAL PLASMA AND SPERMATOZOA WITH ERYTHROCYTES FROM DIFFERENT SPECIES

\begin{tabular}{|c|c|c|c|c|c|c|c|c|c|c|}
\hline \multirow{3}{*}{ Serum* } & \multicolumn{10}{|c|}{ Erythrocytes } \\
\hline & $H u$ & & \multirow[b]{2}{*}{ Rabbit } & \multirow[b]{2}{*}{ Rat } & \multirow[b]{2}{*}{ Sheep } & \multirow[b]{2}{*}{ Bovine } & \multirow[b]{2}{*}{ Possum } & \multirow[b]{2}{*}{ Horse } & \multirow[b]{2}{*}{ Chicken } & \multirow[b]{2}{*}{ Duc } \\
\hline & $A, B$ or & Bombay & & & & & & & & \\
\hline Normal mouse & 4 to 16 & 2 & 2 & 4 & 4 & 2 & 2 & 4 & 16 & 8 \\
\hline $\begin{array}{l}\text { Mouse anti- } \\
\text { human seminal } \\
\text { plasma }\end{array}$ & 512 & 1024 & 2 & 4 & 4 to 8 & 2 & 2 & 2 & 64 & 32 \\
\hline $\begin{array}{l}\text { Mouse anti- } \\
\text { human sperm. }\end{array}$ & 512 & 512 & 2 & 4 & 4 & 2 & 2 & 2 & 32 & 16 \\
\hline
\end{tabular}

* All heated at $56^{\circ}$ to $58^{\circ} \mathrm{C}$ for $30 \mathrm{~min}$.

$\dagger$ Figures in the columns indicate the reciprocals of the last dilutions of sera showing haemagglutination scores of at least $1+$. 


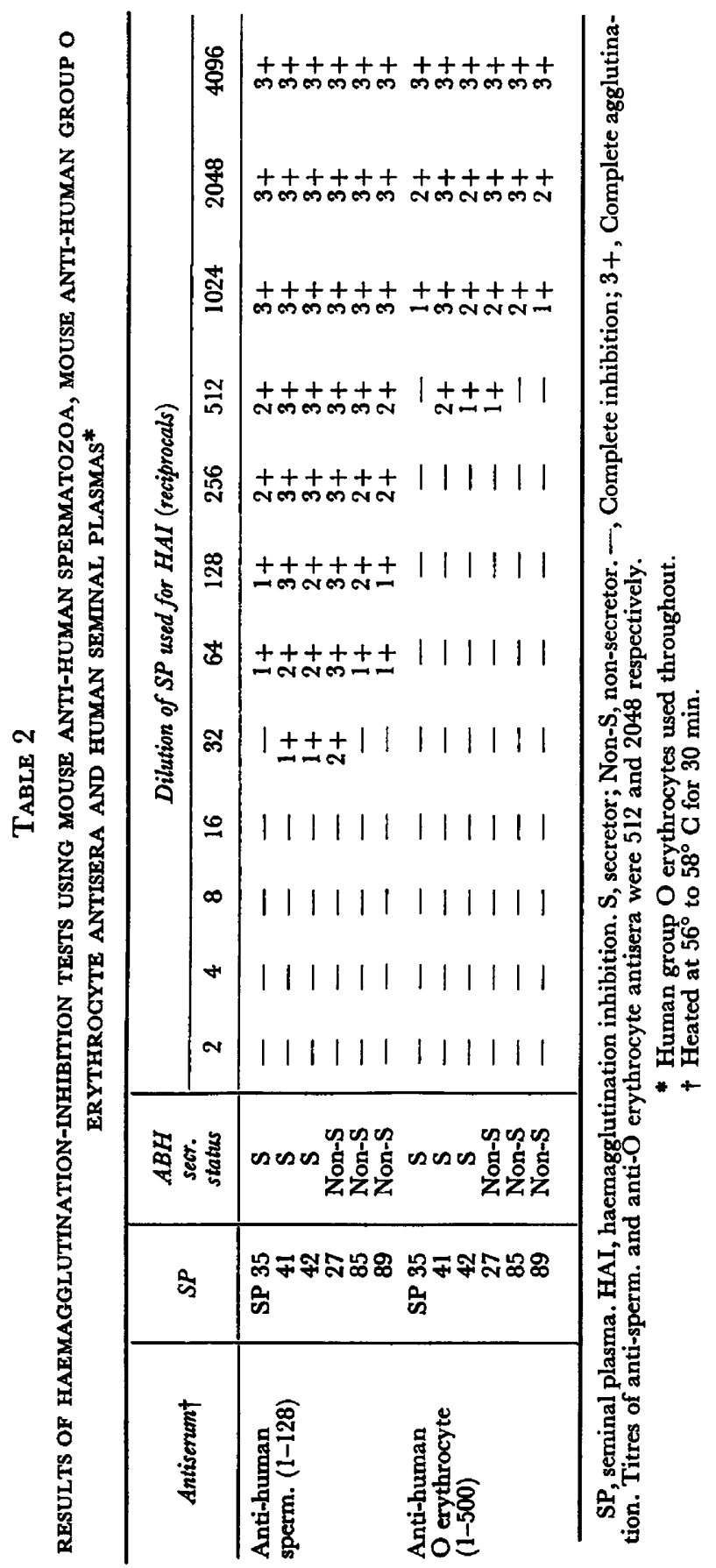


antisera were directed against antigens other than the $\mathrm{ABH}$ antigens. This conclusion was supported by the haemagglutination-inhibition experiments using human secretor and non-secretor seminal plasma. Both types of seminal plasma were found to inhibit equally the haemagglutination of human group $\mathrm{O}$ erythrocytes by mouse anti-human spermatozoa and mouse anti-human seminal plasma (Table 2). When the same samples were tested for haemagglutination inhibition with mouse anti-human $\mathrm{O}$ erythrocyte antiserum, equal inhibition was found to occur with secretor and non-secretor samples (Table 2). Although mouse anti-human seminal plasma and mouse anti-human spermatozoa were found to cause agglutination of fresh motile spermatozoa in a microagglutination test, mouse anti-O erythrocyte antiserum proved to be no better than normal mouse serum in causing such agglutination (Table 3 ).

TABLE 3

COMPARISON OF THE SPERMAGgLUTINATING ACTIVITY OF NORMAL MOUSE, MOUSE ANTI-HUMAN O ERYTHROCYTE, MOUSE ANTI-HUMAN SEMINAL PLASMA AND MOUSE ANTI-SPERM ANTISERA

\begin{tabular}{l|c|c}
\hline \multicolumn{1}{c|}{ Serum* } & $\begin{array}{c}\text { Time } \\
\text { sampled } \\
(\text { min })\end{array}$ & $\begin{array}{c}\text { Spermagglutination score } \\
(\text { No. of agglutinates seen }) \\
100 \text { motile sperm. })\end{array}$ \\
\hline Normal mouse & 15 & 1 \\
& 45 & 1 \\
120 & 3 \\
Anti-human O erythrocyte & 15 & 2 \\
& 45 & 0 \\
Anti-human SP & 120 & 1 \\
& 15 & 40 \\
Anti-human sperm. & 120 & Many small clumps \\
& 15 & Massive clumps \\
& 45 & Many small clumps \\
& 120 & Massive clumps \\
\hline
\end{tabular}

* All heated at $56^{\circ}$ to $58^{\circ} \mathrm{C}$ for $30 \mathrm{~min}$.

Comparisons with the non-immune rabbit and mouse sera show that, as for the human, both the seminal plasma and the spermatozoa of the rabbit, possum and ram, induce antibodies which agglutinate erythrocytes from the same species (Tables 4 and 5). Antisera to rat vas deferens and epididymis also agglutinated rat erythrocytes to high titres (Table 4). Rabbit anti-rooster seminal plasma agglutinated chicken erythrocytes to a titre of 128 , but the anti-rooster spermatozoa was only marginally better than normal rabbit serum in producing agglutination of chicken erythrocytes (Table 4).

Rabbit anti-bull seminal plasma and anti-bull spermatozoa, previously heated to destroy haemolytic activity, did not agglutinate bovine erythrocytes, but unheated anti-bull seminal plasma showed a powerful haemolytic effect for both bovine and sheep erythrocytes (Table 5). A haemolytic effect on sheep erythrocytes was also produced by unheated anti-bull spermatozoa antiserum. Both anti-bull spermatozoa and anti-bull seminal plasma, after heating, agglutinated sheep erythrocytes (Table 5). 
TABLE 4

RESULTS OF HA EXPERIMENTS USING NORMAL SERA AND SERA FROM IMMUNIZED RABBITS AND MICE INJEGTED WITH SEMINAL PLASMA AND SPERMATOZOA FROM VARIOUS SPEGIES

\begin{tabular}{l|c|c}
\hline \multicolumn{1}{c|}{ Serum* } & $\begin{array}{c}\text { Test } \\
\text { erythrocytes }\end{array}$ & $\begin{array}{c}\text { Last dilution of serum } \\
\text { showing HA (reciprocals) }\end{array}$ \\
\hline Normal mouse & Rabbit & 2 \\
M anti-rabbit SP & Rabbit & 256 \\
M anti-rabbit sperm. & Rabbit & 16 \\
Normal rabbit & Possum & 4 \\
R anti-possum SP & Possum & 256 \\
R anti-possum sperm. & Possum & 128 \\
Normal rabbit & Chicken & 4 \\
R anti-rooster SP & Chicken & 128 \\
R anti-rooster sperm. & Chicken & 8 \\
Normal rabbit & Rat & 4 \\
R anti-rat vas deferens & Rat & 128 \\
R anti-rat epididymis & Rat & 256 \\
& & \\
\hline
\end{tabular}

HA, haemagglutination. $M$, mouse; $R$, rabbit. SP, seminal plasma.

* Heated at $56^{\circ}$ to $58^{\circ} \mathrm{G}$ for $30 \mathrm{~min}$.

\section{TABLE 5}

RESULTS OF HA EXPERIMENTS USING NORMAL SERA AND SERA FROM IMMUNIZED RABBITS INJEGTED WITH SEMINAL PLASMA AND SPERMATOZOA FROM RAM AND BULL

\begin{tabular}{l|c|c|c}
\hline \multicolumn{1}{c|}{ Serum } & $\begin{array}{c}\text { Test } \\
\text { erythrocytes }\end{array}$ & $\begin{array}{c}\text { Last dilution of serum } \\
\text { showing haemolysis }\end{array}$ & $\begin{array}{c}\text { Last dilution of } \\
\text { serum showing HA }\end{array}$ \\
\cline { 1 - 2 } Unheated & $<2$ & 2 \\
Normal rabbit & Sheep & $<2$ & 128 \\
Anti-ram SP & Sheep & 32 & + \\
Anti-ram sperm. & Sheep & 32 & + \\
Anti-ram SP & Bovine & 8 & $<2$ \\
Anti-ram sperm. & Bovine & $<2$ & $<2$ \\
Normal rabbit & Bovine & $<2$ & 128 \\
Anti-bull SP & Bovine & 64 & $<2$ \\
Anti-bull sperm. & Bovine & $<2$ & + \\
Anti-bull SP & Sheep & 64 & + \\
Anti-bull sperm. & Sheep & 32 & 2 \\
\hline Heated* & & & 64 \\
Normal rabbit & Sheep & - & 32 \\
Anti-ram SP & Sheep & - & $<2$ \\
Anti-ram sperm. & Sheep & - & $<2$ \\
Normal rabbit & Bovine & - & 2 \\
Anti-ram SP & Bovine & - & $<2$ \\
Anti-ram sperm. & Bovine & - & 64 \\
Anti-bull SP & Bovine & - & 16 \\
Anti-bull sperm. & Bovine & - & - \\
Anti-bull SP & Sheep & - & - \\
Anti-bull sperm. & Sheep & - & \\
\hline
\end{tabular}

HA, haemagglutination. SP, seminal plasma. +, No HA beyond haemolytic titre.

* $56^{\circ}$ to $58^{\circ} \mathrm{C}$ for $30 \mathrm{~min}$. 
The findings of this study can be compared with the results of some other workers.

In common with the conclusion reached by Popivanov \& Vulchanov (1961, 1968), antibody to human spermatozoa was found to cross-react with human erythrocytes, regardless of the $\mathrm{ABO}$ blood type tested, whereas anti-human erythrocyte antiserum showed no agglutination of motile human spermatozoa. This latter observation led Popivanov \& Vulchanov to conclude that complete antigenic identity between the common antigen of the human spermatozoon and erythrocyte does not exist (Popivanov \& Vulchanov, 1961).

In our experiments, human seminal plasma was found to elicit the formation of red cell agglutinating antibody as well as human spermatozoa. Equal reactivity of the two antisera against red cells of all $\mathrm{ABO}$ blood groups and 'Bombay' cells, inhibition of the haemagglutination by both secretor and nonsecretor seminal plasma and the fact that little, if any, cross-reaction was observed between the antisera and the other animal erythrocytes, showed that the antibody was not directed against $\mathrm{ABH}$ antigens, but against what may be termed a 'species' antigen for want of a more definitive description.

In studying the species of origin of cells maintained in tissue culture by the technique of mixed agglutination, Coombs, Bedford \& Rouillard (1956) and Coombs, Daniel, Gurner \& Kelus (1961) have said that the occurrence of mixed agglutination using antisera to red cells, depends on the presence of antigens characteristic of the species and common to both tissue cells and erythrocytes. In the mixed agglutination which they observed using human spermatozoa, $\mathrm{O}$ erythrocytes and anti-human $\mathrm{O}$ erythrocyte antiserum, Edwards et al. (1964) found that the distribution of the antigen(s) involved in the agglutination was uniform over the head and tail of the sperm cells. Although Edwards et al. (1964) consider that the antigen(s) are an intrinsic part of the outer membrane of the human spermatozoa, their distribution over the whole sperm surface suggests another possible explanation for their origin. Results presented in this paper (Tables 1 and 2), have shown that the 'species' antigen(s) in question is also present in human seminal plasma. It seems possible therefore, that the ejaculated spermatozoa, being bathed in a solution of the antigen(s), adsorb the antigen(s) over their entire surface. A number of seminal plasma antigens are already known to be adsorbed to spermatozoa in man and in a variety of other animals (Weil, 1967). Alternatively, the antigens may:

(i) originate on the spermatozoa and be released by degenerating spermatozoa into the surrounding seminal plasma. Leaching of sperm antigens into the surrounding fluid has been discussed by Willson \& Katsh (1965), who have observed that the supernatant fluid of a guinea-pig sperm suspension obtained by centrifugation, contained aspermatogenic antigen, or,

(ii) be common to both seminal plasma and spermatozoa.

The spermatozoa-erythrocyte cross-reactions observed by Rosenthal (1912) and by Piko \& Tyler (1963), however, were obtained using testicular ram spermatozoa and epididymal Chinese hamster spermatozoa, respectively. 
This study was designed simply to examine whether or not immunological cross-reaction of any sort occurs between antisera to the semen with the erythrocytes of a number of species. The results show that the type of crossreaction previously reported for man and for the ram is not confined to these species.

Menge et al. (1962) claim to have observed no cross-reaction between bovine anti-rabbit semen and rabbit erythrocytes. This may have been due to the method of immunization employed. No adjuvant was used, but even so a titre of 1 in 16 against rabbit erythrocytes was reported compared to a titre of 1 in 4 for normal bovine serum. Adsorption of this antiserum with washed rabbit spermatozoa reduced the titre to 1 in 4 .

In 1900, Moxter showed that the serum from rabbits immunized with ram spermatozoa possessed haemolytic properties for sheep erythrocytes. Rosenthal (1912), using rabbit antiserum to testicular ram spermatozoa, confirmed Moxter's finding and concluded that the antibodies to ram spermatozoa were different from the antibodies to ram erythrocytes since the former showed a greater avidity for ram spermatozoa than did anti-ram erythrocyte antiserum. The results of these workers have been supported by the present investigation. Again, however, seminal plasma was found to be at least as strong as spermatozoa in stimulating the formation of haemolysins. The failure by Rosenthal to obtain haemolysis of bovine erythrocytes with rabbit anti-ram spermatozoa has been confirmed here, but some haemolysis occurred with the anti-seminal plasma we used.

Some recent findings of Drevius (1968) are relevant to the haemagglutination results obtained here using anti-bull and anti-ram seminal material. Drevius found that normal rabbit serum lysed sheep erythrocytes but we (and Edwards, 1960) did not find such haemolysins. The same author concluded that the antigen in bull semen responsible for eliciting the production of sheep haemolysins is to be found in the seminal plasma rather than on the spermatozoa. In our experiments, rabbit anti-bull spermatozoa as well as anti-bull seminal plasma were found to induce haemolysis of sheep erythrocytes and this may have been due to adsorbed seminal plasma antigens. Drevius (1968) found no haemolysis between anti-bull semen and bovine erythrocytes and, while we found this to be true when rabbit anti-bull spermatozoa were titrated, anti-bull seminal plasma was found to show haemolytic activity towards bovine erythrocytes. However, after inactivation of the anti-bull seminal plasma at $56^{\circ} \mathrm{C}$, no thermostable haemolysins or agglutinins remained.

Drevius injected rabbits intravenously with adjuvant-free solutions containing $5 \%$ spermatozoa and $5 \%$ seminal plasma, so it is possible that these differences may have been due to the degrees of immunity achieved by the respective immunization methods. In our experiments, the anti-rooster spermatozoa antiserum did not show significant cross-reaction with chicken erythrocytes. However, a longer and more intensive immunization schedule with rooster spermatozoa may detect adsorbed seminal plasma antigens since, in all cases where anti-seminal plasma antisera caused haemagglutination, the corresponding anti-spermatozoa antiserum was also found to produce haemagglutination.

Although excision of the rat organs was carried out with the aim of excluding 
as much extraneous tissue as possible, the complete exclusion of erythrocytes in such cases is difficult. For this reason, it cannot be completely discounted that the haemagglutination titres obtained with antisera to the rat organs may have been due to immunization of the injected rabbits with a small number of rat erythrocytes.

The rabbit does not possess Forssman (F) antigen, whereas the sheep and rooster do (Forssman, 1911; Gushing \& Campbell, 1957). Consequently, it seems possible that antibodies developed in the rabbit against tissues from the latter species could be directed against the $\mathrm{F}$-antigen. This is a possible explanation for the cross-reactions seen with the semen and erythrocytes from sheep and rooster.

\section{ACKNOWLEDGMENTS}

The authors are indebted to Dr R. T. Simmons, Commonwealth Serum Laboratories, Parkville, Victoria, for the supply of 'Bombay' erythrocytes. This work was carried out while one of us (B.A.B.) held the 1967 Kodak Scholarship.

\section{REFERENCES}

BALdo, B. A. \& BoETTCHER, B. (1970) Natural erythrocyte agglutinins in the serum of the Australian freshwater catfish, Tandanus tandanus (Mitchell). I. Examination of the specificities of the agglutinins with emphasis on the ABH agglutinins. Immunology, 19, 569.

Boettcher, B. (1968) Correlation between human ABO blood group antigens in seminal plasma and on seminal spermatozoa. F. Reprod. Fert. 16, 49.

Coombs, R. R. A., BeDford, D. \& Routllard, L. E. (1956) A and B blood group antigens on human epidermal cells demonstrated by mixed agglutination. Lancet, $\mathbf{i}, 461$.

Coombs, R. R. A., Daniel, M. R., Gurner, B. W. \& Kelus, A. (1961) Recognition of the species of origin of cells in culture by mixed agglutination. I. Use of antisera to red cells. Immunology, 4,55 .

Cushing, J. E. \& Gampbeld, D. H. (1957) The nature of antigens. In: Principles of Immunology, p. 236. McGraw-Hill, New York.

Docton, F. L., Ferguson, L. C., LAzear, E. J. \& Ely, F. (1952) The antigenicity of bovine spermatozoa. 7. Dairy Sci. 35, 706.

DREvrus, L.-O. (1968) On the mechanism of sperm immobilization induced by normal sera and antisemen sera. Expl Cell Res. 51, 362.

Edwards, R. G. (1960) The complement-fixing activity of normal rabbit serum with rabbit spermatozoa and seminal plasma. F. Reprod. Fert. 1, 268.

Edwards, R. G., Ferguson, L. G. \& CoomBs, R. R. A. (1964) Blood group antigens on human spermatozoa. F. Reprod. Fert. 7, 153.

Forssman, J. (1911) Die Herstellung hochwertiger spezifischer Schafhämolysine ohne Verwendung von Schafblut. Ein Beitrag zur Lehre von heterologer Antikorperbildung. Biochem. Z. 37, 78.

GULlbring, B. (1957) Investigation on the occurrence of blood group antigens in spermatozoa from man, and serological demonstration of the segregation of characters. Acta med. scand. 159, 169.

LANDSTEiner, L. (1945) The specificity of serological reactions, 2nd edn, p. 79. Harvard University Press, Cambridge, Mass. Reprinted Dover Publ. Inc., New York, 1967.

Lawler, S. D. \& Shatwell, H. S. (1962) Are Rh antigens restricted to red cells? Vox Sang. 7, 488.

Levine, P. \& Celano, M. J. (1961) The question of $D$ (Rho) antigenic sites on human spermatozoa. Vox Sang. 6, 720.

MATouseK, J. (1964) Antigenic characteristics of spermatozoa from bulls, rams and boars. I. Erythrocytic antigens in bull spermatozoa. F. Reprod. Fert. $8,1$.

Menge, A. C., Stone, W. H., Tyler, W. J. \& Gasma, L. E. (1962) Immunological studies on fertility and sterility. IV. Fertility of cattle and rabbits inseminated with semen treated with antibodies produced against semen, spermatozoa and erythrocytes. F. Reprod. Fert. 3, 331.

Moxtzr, H. (1900) Ueber ein Spezifisches Immunserum gegen Spermatozoen. Dt. med. Wschr. 26, 61.

Piko, L. \& Tyler, A. (1963) Tissue- and species-specificity of Chinese hamster sperm antigens. Am. Zool. 3, 504 . 
Popivanov, R. \& Vulchanov, V. H. (1961) Identity and differences in the behaviour of species antigens in man's spermatozoa and erythrocytes. C. r. Acad. bulg. Sci. 14, 223.

Popivanov, R. \& Vulchanov, V. H. (1962) On the character and interrelations of the species-specific antigens (agglutinogens) of human spermatozoa and erythrocytes. Izv. mikrobiol. Inst., Sof. Acad. Sci. 13,81.

Popivanov, R. \& Vulchanov, V. H. (1968) Immunogenetics of human spermatozoa. In: Immunology and Reproduction, p. 155. Proc. First Symp. Int. Coord. Committee for the Immunology of Reproduction, Geneva. Ed. R. G. Edwards. International Planned Parenthood Federation, London.

Quintrvan, W. L. G. \& Masouredis, S. P. (1962) $\mathrm{Rh}_{\mathrm{o}}$ (D) antigen content of human spermatozoa. Immunology, 5, 267.

Rosenthal, F. (1912) Zur Kenntnis der hamolytischen Komponente spermotoxischer Immunsera. Biochem. Z. 42, 7.

Stone, W. H. (1962) The J substance of cattle. Ann. N.Y. Acad. Sci. 97, 267.

Stone, W. H. (1964) The significance of immunologic phenomena in animal reproduction. Proc. 5th Int. Congr. Anim. Reprod. Trento, 2, 89.

WeIL, A. J. (1967) Antigens of the seminal plasma. 7. Reprod. Fert., Suppl. 2, 25.

WrLlson, J. T. \& Katsch, S. (1965) Cyto-immunological studies of guinea pig sperm antigens. I. Testicular versus epididymal spermatozoa. Z. Zellforsch. mikrosk. Anat. 65, 16. 